\title{
Blood Cell Morphology and Plasma Biochemistry of the Captive European Pond Turtle Emys orbicularis
}

\author{
K. METIN ${ }^{1}$, O. TÜRKOZAN ${ }^{1}$, F. KARGIN ${ }^{2}$, Y. BASIMOGLU KOCA ${ }^{1}$, \\ E. TASKAVAK ${ }^{3}, \mathrm{~S}$. KOCA ${ }^{1}$ \\ ${ }^{1}$ Adnan Menderes University, Faculty of Science and Arts, Department of Biology, \\ Aydin, Turkey \\ ${ }^{2}$ Adnan Menderes University, Faculty of Veterinary Medicine, Department of Biochemistry, \\ Aydin, Turkey \\ ${ }^{3}$ Ege University, Faculty of Fisheries, \\ Bornova-Izmir, Turkey
}

Received January 10, 2005

Accepted November 10, 2005

\begin{abstract}
Metin K., O. Türkozan, F. Kargin, Y. K. Basimoglu, E. Taskavak, S. Koca: Blood Cell Morphology and Plasma Biochemistry of the Captive European Pond Turtle Emys orbicularis. Acta Vet. Brno 2006, 75: 49-55.

The morphological characteristics of peripheral blood cells, micronucleated erythrocytes counts and plasma biochemistry profile were examined in ten healthy captive European pond turtles Emys orbicularis. Blood samples were obtained from the caudal vein. The Wright staining method was used for the classification of the blood cells. Mature erythrocytes of captive Emys orbicularis were nucleated ellipsoidal cells $(21.7 \pm 1.27 \mu \mathrm{m} \times 13.2 \pm 1.12 \mu \mathrm{m})$ with pink cytoplasm. The nucleus $(6.9$ $\pm 0.78 \mu \mathrm{m} \times 5.4 \pm 0.65 \mu \mathrm{m})$ was centrally located and stained dark purple. Seven different types of blood cells were determined: erythrocytes, thrombocytes, monocytes, eosinophils, basophils, lymphocytes and heterophils. The micronucleated erythrocyte (MNE) values were 0.0016 and 0.003 for the males and females, respectively. The MNE results were presented as the mean frequency of micronucleated erythrocytes per 1000 cells per animal.

The mean plasma concentrations in the total of specimens were as follows: total protein $(25 \mathrm{~g} / \mathrm{L})$, albumin $(7.2 \mathrm{~g} / \mathrm{L})$, globulin $(17.8 \mathrm{~g} / \mathrm{L})$, glucose $(2.91 \mathrm{mmol} / \mathrm{L})$, calcium $(2.32 \mathrm{mmol} / \mathrm{L})$, phosphorus $(1.55 \mathrm{mmol} / \mathrm{L})$, creatinine $(46.85 \mu \mathrm{mol} / \mathrm{L})$, urea $(10.93 \mathrm{mmol} / \mathrm{L})$, triglycerides $(0.44$ $\mathrm{mmol} / \mathrm{L})$, cholesterol $(1.48 \mathrm{mmol} / \mathrm{L})$, sodium $(125.76 \mathrm{mmol} / \mathrm{L})$, potassium $(3.98 \mathrm{mmol} / \mathrm{L})$, chloride $(93.94 \mathrm{mmol} / \mathrm{L})$, iron $(13.34 \mu \mathrm{mol} / \mathrm{L})$ and activities of aspartate aminotransferase $(2.14 \mu \mathrm{kat} / \mathrm{L})$, alanine aminotransferase $(0.15 \mu \mathrm{kat} / \mathrm{L})$, gamma glutamyl transpeptidase $(2.15 \mathrm{U} / \mathrm{L})$, amylase $(8.09 \mu \mathrm{kat} / \mathrm{L})$, lactate dehydrogenase $(19.93 \mu \mathrm{kat} / \mathrm{L})$. We found sex-dependent differences only in $\operatorname{ALT}[(0.21 \mu \mathrm{kat} / \mathrm{L}$ and $0.10 \mu \mathrm{kat} / \mathrm{L}$ for the males and females, respectively) $(\mathrm{t}=3,107 ; \mathrm{df}=14 ; p<0.05)]$ value in the blood biochemical profile for healthy Emys orbicularis.

We suggest that the biochemical profile described in the present study may be used as a standard profile for healthy Emys orbicularis kept in captivity.
\end{abstract}

Haematology, plasma biochemistry, Reptilia, Chelonia, Emys, micronucleus

The distribution of Emys orbicularis (Linnaeus 1758) extends from Northwest Africa, through almost all of Central Europe, including the Iberian Peninsula and the Mediterranean islands of Corsica, Sardinia, Sicily, the Balkan Peninsula, and western Asia (Snieshkus 1995).

Various authors have described different circulating blood cells of different amphibian and reptile species (Mateo et al.1984; Canfield and Shea, 1988; Knotková et al. 2002; Azevedo et al. 2003). Blood biochemistry represents a valuable diagnostic tool for monitoring the health and condition of free-ranging wildlife. Comparative studies of clinically healthy and diseased turtles can provide insightful information for their management and conservation (Bolten and Bjorndal 1992; Hasbun et al.1998). Understanding the blood composition of turtles is very important for preventing and treating

Address for correspondence:

Oguz Türkozan

Adnan Menderez University

Faculty of Science and Arts

Department of Biology

Phone: +90 25621284 98/2218

09010 Aydin, Turkey

Fax: +90 2562135379

E-mail: turkozan@adu.edu.tr

http://www.vfu.cz/acta-vet/actavet.htm 


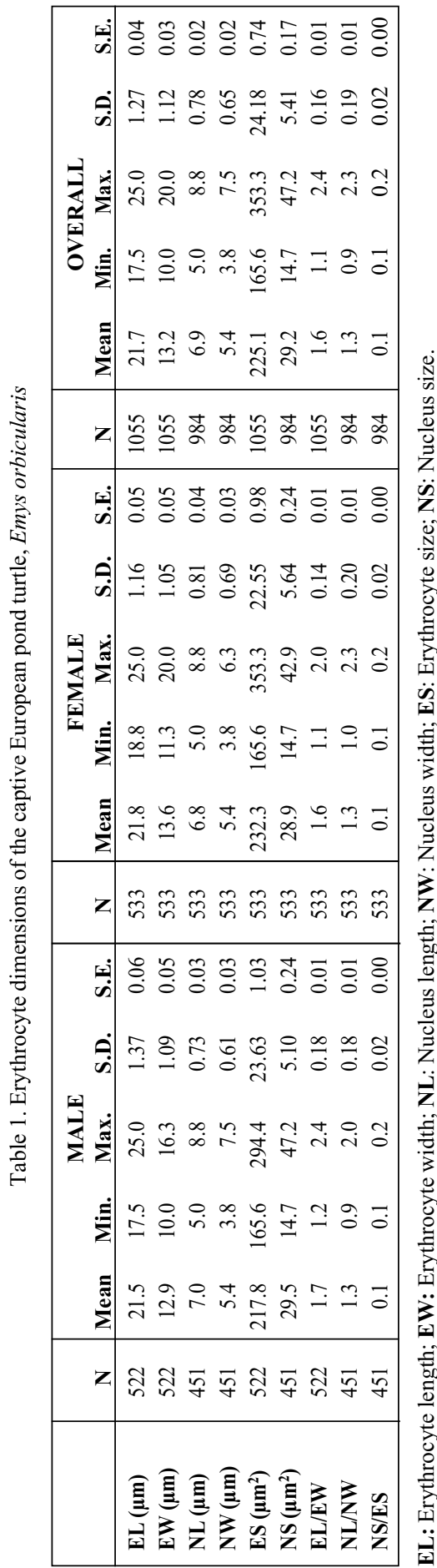

many illnesses as well. There are many papers that characterize the blood of land tortoises (Allemann et al.1992; Garner et al. 1996; Muro et al. 1998; Knotková et al. 2002) however, little is known about the haematology and blood biochemistry of Emys orbicularis (Kölle et al. 1999; Ugurtas et al. 2003).

The identification of morphological characteristics of different peripheral blood cells and plasma biochemistry profile of healthy Emys orbicularis kept in captivity was the purpose of this study. The aim of this work was to develop reference values for the main haematological and biochemical variables of Emys orbicularis. We can thus have an objective method for health assessment which is essential for any conservation.

\section{Materials and Methods}

Animals

Twenty adult European pond turtles, 10 males and 10 females were studied at a private captive breeding farm in the month of July. The specimens were kept in vessels (200 $\times 200 \times 60 \mathrm{~cm})$ at the farm, and we were informed that they were fed with commercial trout food, dog food, sardines, anchovies, chopped chicken liver and sheep stomach. The mean straight carapace lengths were $10.06 \pm 0.17$ and 13.0 $\pm 0.38 \mathrm{~cm}$ for the males and females, respectively. The females were checked by manual examination through the cloaca for eggs in oviducts. All of them were determined as non-pregnant.

\section{Blood sampling}

A blood specimen of each turtle was taken by venepuncture from the caudal vein. Blood (1-2 ml) was collected using 21 gauge needles and $5 \mathrm{ml}$ syringes. Blood specimens were transferred into Vacutainer tubes containing lithium heparin and placed on ice until processing in the laboratory 4-6 h after capture. Plasma was separated by centrifugation at $3000 \mathrm{rpm}$ for 10 minutes and split in two or more vials.

\section{Blood cell morphology}

Of the 20 European pond turtles, 10 (5 후, 5 오 오), were used for blood cell morphology. Blood samples were taken from the caudal vein. Blood smears were prepared immediately and air-dried. Wright-stained blood smears were used for the measurement and assessment of blood cells. Four to five blood smears were prepared per individual. On each slide lengths (EL) and widths (EW) of randomly selected 100 mature erythrocytes and their nuclei (NL and NW), fifty thrombocytes, heterophil, eosinophil, basophil, lymphocyte and 20 monocyte were measured by an Olympus ocular micrometer at a magnification of $600 \times$. Erythrocyte and nuclear sizes (ES and NS) were calculated according to formulas $[(\mathrm{EL} \times \mathrm{EW} \times \pi) / 4]$ and $[(\mathrm{NL} \times \mathrm{NW} \times \pi) / 4]$, respectively. In addition, micronucleated erythrocytes were counted among 1000 erythrocytes on each blood smears by the same micrometer at a magnification of $1000 \times$. 


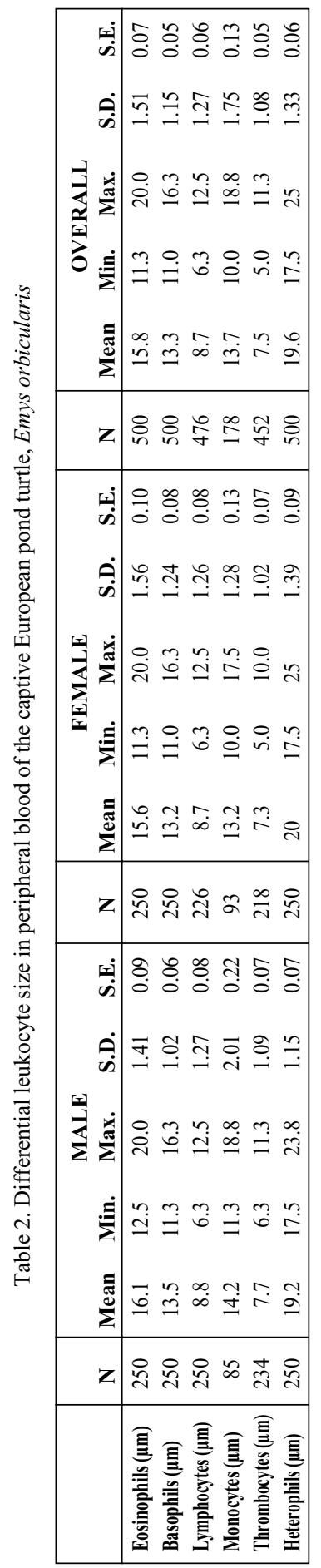

Plasma biochemistry

Biochemical indices of plasma were measured spectrophotometrically (Microlab Merck 200) by means of commercial kits (Biomedical Biosystems/Spain). $\mathrm{Na}, \mathrm{K}$ and $\mathrm{Cl}$ were measured by means of an ion selective device. Samples that appeared haemolysed were discarded. The following plasma were measured: aspartate aminotransferase (EC 2.6.1.1), alanine aminotransferase (EC 2.6.1.2), gamma glutamyl transpeptidase (EC 2.3.2.2), amylase (EC 3.2.1.1), lactate dehyrogenase (EC 1.1.1.27), total protein, albumin, glucose, creatinine, urea, triglycerides, cholesterol, calcium $(\mathrm{Ca})$, phosphorus $(\mathrm{P})$, sodium $(\mathrm{Na})$, potassium $(\mathrm{K})$, chloride $(\mathrm{Cl})$ and iron $(\mathrm{Fe})$. Blood chemical values are expressed in SI units.

Statistical analyses

Haematological and biochemical variables were summarized as mean, standard deviation (SD), standard error of the mean (SE) and range. We used analysis of variance (ANOVA) and the $t$ test for a comparison of the sexes. Results were considered significant at $p<0.05$. Statistical analyses were carried out by using STATISTICA version 6.0.

\section{Results}

Blood cell morphology

Mature erythrocytes of captive Emys orbicularis were nucleated ellipsoidal cells $(21.7 \pm 1.27 \mu \mathrm{m} \times 13.2 \pm 1.12 \mu \mathrm{m})$ with pink cytoplasm (Fig. 1A). The nucleus $(6.9 \pm 0.78 \mu \mathrm{m}$ $\times 5.4 \pm 0.65 \mu \mathrm{m})$ was centrally located and stained dark purple under Wright' stain. One-way ANOVA verified sexual dimorphism in terms of EL $(\mathrm{F}=5,654 ; p<0.05)$, EW $(\mathrm{F}=81,425 ; p<0.0001), \mathrm{NL}(\mathrm{F}=7.991 ; p<0.05), \mathrm{ES}(\mathrm{F}=$ $72.870 ; p<0.0001) \mathrm{NS}(\mathrm{F}=3.928 ; p<0.05)$ and $\mathrm{EL} / \mathrm{EW}(\mathrm{F}=$ $40.249 ; p<0.0001)$. Results of erythrocyte measurements are summarized in Table 1.

Five types of leucocytes were identified as heterophils, eosinophils, basophils, lymphocytes and monocytes. The descriptive statistics of the leucocytes are presented in Table 2. The mean diameter of the eosinophils was $15.8 \mu \mathrm{m} \pm 1.51$ with blue circular or oval nucleus (Plate II, Fig. 1B). The nucleus sometimes consisted of two lobes and was positioned eccentrically. The cytoplasm was pink-red and filled with rough round granules.

Heterophils were $19.6 \mu \mathrm{m} \pm 1.33$ in diameter and not always round in shape. The eccentrically positioned nucleus of heterophil (Fig. 1C) was round to oval and pale blue. The pale pink cytoplasm was filled with irregular spindle-shaped granules.

Basophils (Fig. 1D) were $13.3 \mu \mathrm{m} \pm 1.15$ in diameter with a round and centrally positioned nucleus. The cytoplasm was filled with large round granules with a colour varying from dark blue to dark purple-black.

Lymphocytes (Fig. 1A) were $8.7 \mu \mathrm{m} \pm 1.27$ in diameter with a large, dark and intense centrally positioned nucleus. Light blue cytoplasm covered a narrow area around the nucleus.

Monocytes (Fig. 1E) were $13.7 \mu \mathrm{m} \pm 1.75$ in diameter with 


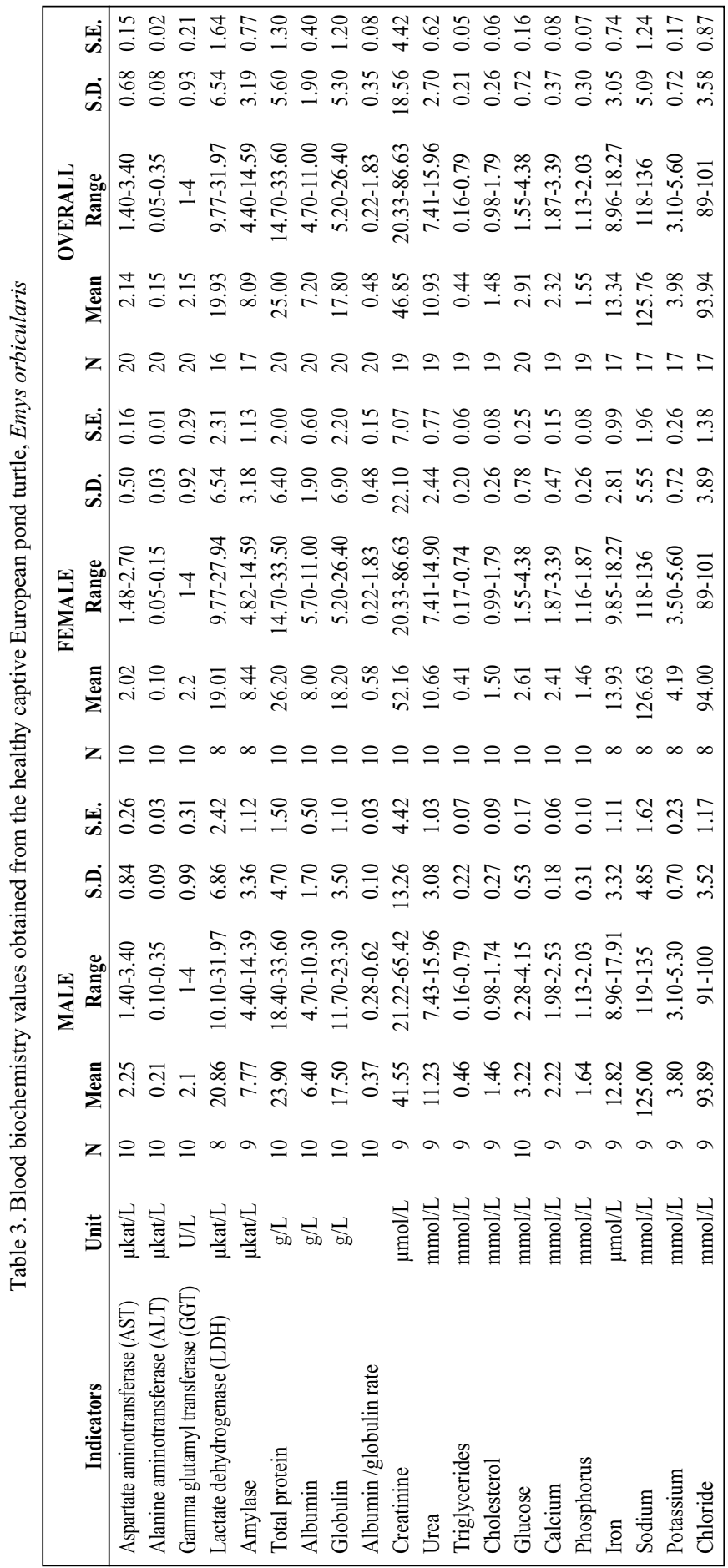

an oval and kidney-shaped nucleus, which was less intense and contained pale chromatin. The cytoplasm was grey blue and covered more area.

The nucleus of thrombocytes (Fig. 1F), which formed cell groups on blood smears, was round to oval and dark. The cytoplasm was blue-purple and positioned around the nucleus. The diameter of the thrombocytes was 7.5 $\mu \mathrm{m} \pm 1.08$.

Plasma biochemistry

We have seen sex-dependent differences only in the ALT value $(\mathrm{t}=$ $3.107 ; \mathrm{df}=14 ; p<0.05)$ in blood biochemistry profile in healthy Emys orbicularis. Results of plasma biochemistry analyses are summarized in Table 3.

Micronucleated erythrocytes (MN)

The micronucleated erythrocyte (MNE) values were 0.0016 and 0.003 for the males and females, respectively. The micronucleated erythrocyte counts and values in 1000 erythrocytes of 10 captive (5 o, 5 우) Emys orbicularis are given in Table 4.

\section{Discussion}

According to a detailed survey of Saint Girons (1970), the largest erythrocytes in reptiles belong to the member of an ancient group, the tua- 
Table 4. Micronucleated peripheral erythrocytes in ten captive European pond turtles, Emys orbicularis

\begin{tabular}{|l|c|c|c|}
\hline Gender & $\mathrm{N}$ & Individual animal counts/1000 erythrocytes & Micronucleated erythrocyte/1000 \\
\hline Male & 5 & $1 / 4 / 2 / 1 / 0$ & 0.0016 \\
Female & 5 & $2 / 1 / 1 / 10 / 1$ & 0.003 \\
\hline
\end{tabular}

tara (Sphenedon punctatus), followed by those of turtles and crocodilians. Erythrocytes are morphologically similar among various species of reptiles (S aint Girons 1970). The erythrocytes of Russian tortoises, Agrionemys horsfieldi, were reported to be long or irregular in shape (Knotková et al. 2002). Mature erythrocytes of the captive European pond turtle (Emys orbicularis) were nucleated ellipsoidal cells with a pink stained cytoplasm. The nucleus was positioned centrally, and stained dark purple under Wright' stain. The nucleus in a mature erythrocyte is round in desert tortoises (Gopherus agassizii) (Alllem an et al. 1992; Garner et al. 1996) as well in green turtles (Chelonia mydas) (S a mour et al. 1998; Work et al. 1998). The only blood cell values, which were comparable with those of the natural Emys orbicularis helenica from Turkey, were EL, EW, ES, EL/EW and NS/ES reported by Ugurtas et al. (2003). When the means of our blood cell values were tested with one sample $t$ test against the natural Emys orbicularis population mean; the EW, ES EL/EW and NS/ES values differed significantly $(p<0.0001)$ from those of the captive population.

The classification of reptilian leucocytes poses many problems since these cells show morphological variation within the class, and several different nomenclatures have been used to describe those (Knotková et al. 2002). For example, Saint Girons (1970) reported the presence of eosinophils, azurophils, neutrophils and plasma cells in reptiles, Sypek and Borysenko (1988) described eosinophils and heterophils in the reptilian blood. According to Canfield (1998), the mammalian neutrophil is equivalent to the nonmammalian heterophil. The heterophil, except in mammals, has coarse, red to brown, spiculated to irregular granules of variable size, and either a bilobed (birds and some lizards) or unlobed nucleus (most reptiles and amphibians). Azevedo et al. (2003) observed that 2 types of eosinophilic granulocytes are present in the blood of Chrysemys dorbignih. The eosinophils in the present study had a blue circular or oval nucleus (Fig. 1B). The nucleus sometimes consisted of two lobes and was eccentrically positioned. The cytoplasm was pink-red and filled with rough round granules.

In our study we identified heterophils with eccentrically positioned nuclei, pale blue in colour and round to oval in shape. The pale pink cytoplasm was filled with irregular spindleshaped granules.

Basophils were round with a centrally positioned nucleus. The cytoplasm was filled with large rounded granules, whose colour varied from dark blue to dark purple-black. Rounded, basophilic granules filled the cytoplasm and often partially masked the nucleus, as previously found by Canfield (1998).

Lymphocytes may be small, medium or large (Canfield 1998). Canfield (1998) stated that cytoplasm may contain small vacuoles and azurophilic granules. In the present study, the lymphocytes almost filled the cytoplasm of the cell and had a blue stained nucleus. The amount of cytoplasm was lower and stained in light blue.

Monocytes are large cells with unlobed or lobed nuclei and a large amount of lightly basophilic cytoplasm. Monocytes in the captive Emys orbicularis are irregular with oval and kidney-shaped nuclei, which were less intense and contained pale chromatin. The cytoplasm was grey-blue and expanded over a larger area. They contained a higher amount of lightly basophilic cytoplasm in comparison to lymphocytes.

Knotková et al. (2002) identified two types of thrombocytes in Russian tortoises, Agrionemys horsfieldi: an oval one with a good visible membrane, a faintly stained cytoplasm, and a rectangular one with small projections of lightly basophilic cytoplasm. 
They attributed this variability to ageing, function and artifact. The similarity of thrombocytes and lymphocytes in reptiles is known (Frye 1991). Although this similarity was determined in the captive Emys orbicularis, thrombocytes mostly formed cell groups.

Of the studied blood biochemical variables, sex-dependent differences were recorded only in the ALT value, with females having lower ALT in the healthy Emys orbicularis. Kölle et al. (1999) recorded 16 variables as statistically different between the sexes in Emys orbicularis. Only 11 variables were available for a comparison with those of Kölle et al. (1999). They were Ca, P, ALT, AST, LDH, amylase, glucose, albumin, creatinine, cholesterol and triglycerides. All of the variables, except albumin, showed statistically significant differences $(p<0.0001)$ from our values. These differences may result from seasonal changes in blood parameters, feeding type and age. Pagés et al. (1992) studied the seasonal changes in blood biochemistry of Mauremys caspica leprosa and found that glucose, calcium and magnesium were lower in summer, whereas phosphorus was higher. Only 10 variables were available for a comparison with those of Pagés et al. (1992). They were glucose, urea, $\mathrm{Na}, \mathrm{K}, \mathrm{Ca}, \mathrm{P}$, total protein, albumin, globulin and albumin/globulin. All of the variables except urea and albumin/globulin showed statistically significant differences from our values $(p<0.0001)$. Total protein level was lower than in M.c. leprosa. Urea and albumin/globulin levels were within the range reported for M.c. leprosa. Na, K, $\mathrm{Ca}$ levels were higher than in M.c. leprosa, whereas glucose and phosphorus levels were lower.

The micronucleus count is an indicator of a genetic damage in mature animals. An elevated number of micronucleated cells indicate poor health. However, ZúñigaGonzález et al. (2000) suggested that in new-born animals, the presence of MNE could be increased, as the reticuloendothelial system might be immature in the young of some species. They also noted that the reticuloendothelial system matures with age. In some species of reptiles such as Crocodylus acutus, Pituophis depei and Macroclemys temminckii, the MNE counts were found very low, or no MNE was recorded (Zúñiga-González et al. 2000).

We suggest that the biochemical profile described in the present study may be used as a standard profile for the healthy Emys orbicularis kept in captivity. Nevertheless, some differences may be expected, especially for young turtles with rapid growth and/or for adult females during the reproductive season.

\section{Morfologie krevních buněk a biochemie plasmy želvy Emys orbicularis}

U deseti zdravých želv Emys orbicularis byly zjištovány: morfologická charakteristika buněk periferní krve, počty mikronukleárních erytrocytů a biochemický profil plasmy. Vzorky krve byly získávány z v. caudalis. Pro klasifikaci krevních buněk bylo použito Wrightovo barvení. Zralé erytrocyty želvy Emys orbicularis byly jaderné elipsoidní buňky $(21,7 \pm 1,27 \mu \mathrm{m} \times 13,2 \pm 1,12 \mu \mathrm{m}) \mathrm{s}$ růžovou cytoplasmou. Jádro tmavě fialové barvy (purpurové) $(6,9 \pm 0,78 \mu \mathrm{m} \times 5,4 \pm 0,65 \mu \mathrm{m})$ bylo lokalizováno centrálně. Bylo identifikováno 7 různých typů krevních buněk: erytrocyty, trombocyty, monocyty, eozinofily, bazofily, lymfocyty a heterofily. Počty mikronukleárních erytrocytů (MNE) byly u samců 0,0016 a u samic 0,003. Hodnoty MNE udávají průměrný počet mikronukleárních erytrocytů na 1000 krevních buněk zvířete.

Průměrné plazmatické koncentrace sledovaných ukazatelů vzorků byly následující: celková bílkovina $\left(25 \mathrm{~g} \cdot \mathrm{l}^{-1}\right)$, albumin $\left(7,2 \mathrm{~g} \cdot \mathrm{l}^{-1}\right)$, globulin $\left(17,8 \mathrm{~g} \cdot \mathrm{l}^{-1}\right)$, glukóza $\left(2,91 \mathrm{mmol} \cdot \mathrm{l}^{-}\right.$ $\left.{ }^{1}\right), \mathrm{Ca}\left(2,32 \mathrm{mmol} \cdot \mathrm{l}^{-1}\right), \mathrm{P}\left(1,55 \mathrm{mmol} \cdot \mathrm{l}^{-1}\right)$, kreatinin $\left(46,85 \mu \mathrm{mol} \cdot \mathrm{l}^{-1}\right)$, urea $\left(10,93 \mathrm{mmol} \cdot \mathrm{l}^{-1}\right)$, triglyceridy $\left(0,44 \mathrm{mmol} \cdot \mathrm{l}^{-1}\right)$, cholesterol $\left(1,48 \mathrm{mmol} \cdot \mathrm{l}^{-1}\right)$, Na $\left(125,76 \mathrm{mmol} \cdot \mathrm{l}^{-1}\right), \mathrm{K}(3,98$ $\left.\mathrm{mmol} \cdot \mathrm{l}^{-1}\right), \mathrm{Cl}\left(93,94 \mathrm{mmol} \cdot \mathrm{l}^{-1}\right), \mathrm{Fe}\left(13,34 \mu \mathrm{mol} \cdot \mathrm{l}^{-1}\right)$ a aktivity AST $\left(2,14 \mu \mathrm{kat} \cdot \mathrm{l}^{-1}\right), \operatorname{ALT}(0,15$ _kat $\left.\cdot l^{-1}\right),\left(\right.$ GMT) $\left(2,15 \mathrm{U} \cdot \mathrm{l}^{-1}\right)$, amylázy $\left(8,09 \mu \mathrm{kat} \cdot \mathrm{l}^{-1}\right), \mathrm{LDH}\left(19,93 \mu \mathrm{kat} \cdot \mathrm{l}^{-1}\right)$. Na pohlaví závislé rozdíly biochemického profilu zdravých želv Emys orbicularis jsme pozorovali 
pouze u ALT $\left[\left(0,21 \mu \mathrm{kat} \cdot \mathrm{l}^{-1} \mathrm{u}\right.\right.$ samců a $0,10 \mu \mathrm{kat} \cdot \mathrm{l}^{-1} \mathrm{u}$ samic $\left.)(\mathrm{t}=3,107 ; \mathrm{df}=14 ; p<0.05)\right]$. Navrhujeme používat biochemický profil, popsaný v této studii jako standard pro zdravé želvy Emys orbicularis chované v zajetí.

\section{Acknowledgements}

This study was supported by the Adnan Menderes University grant no. FEF-04004.

\section{References}

ALLEMAN AR, JACOBSON ER, RASKIN RE 1992: Morphologic and cytochemical characteristics of blood cells from the desert tortoise (Gopherus agassizii). Am J Vet Res 53: 1645-1651

AZEVEDO A, LUNARDI LO 2003: Cytochemical characterization of eosinophilic leukocytes circulating in the blood of the turtle (Chrysemys dorbignih). Acta Histochem 105: 99-105

BOLTEN AB, BJORNDAL KA 1992: Blood profiles for a wild population of green turtles (Chelonia mydas) in the southern Bahamas: size-specific and sex-specific relationships. J Wildl Dis 28: 407-413

CANFIELD PJ 1998: Comparative cell morphology in the peripheral blood film from exotic and native animals. Aust Vet J 76: 793-800

CANFIELD PJ, SHEA GM 1988: Morphological observations on the erythrocytes, leukocytes and thrombocytes of blue tongue lizards (Lacertilia: Scincidae, Tiliqua). Anat Histol Embryol 17: 328-342

FRYE FL 1991: Hematology as applied to clinical reptile medicine. In: Reptile care. An atlas of diseases and treatment. TFH Publications Inc., Neptune City, New Jersey, pp. 211 - 277

GARNER MM, HOMER BL, JACOBSON ER, RASKIN RE, HALL BJ, WEIS WA, BERRY KH 1996: Staining and morphologic features of bone marrow hematopoietic cells in desert tortoises (Gopherus agassizii). Am J Vet Res 57: 1608-1615

HASBUN CR, LAWRENCE AJ, NALDO J, SAMOUR JH, AL-GHAIS SM 1998: Normal blood chemistry of free-living green sea turtle, Chelonia mydas from the United Arab Emirates. Comp Haematol Int 8: 174-177

KNOTKOVÁZ, DOUBEK J, KNOTEK Z, HÁJKOVÁ P 2002: Blood cell morphology and plasma biochemistry in Russian tortoises (Agrionemys horsfieldi). Acta Vet Brno 71: 191-198

KÖLLE P, LAMNEK H, HOFFMANN R 1999: Blutwerte bei der Europäischen Sumpfschildkröte (Emys orbicularis). Tierärztl Prax 27: 198-201

MATEO MR, ROBERTS ED, ENRIGHT FM 1984: Morphologic, cytochemical, and functional studies of peripheral blood cells of young healthy American alligators (Alligator mississippiensis). Am J Vet Res 45: 10461053

MURO J, CUENCA R, PASTOR J, VINAS L, LAVIN S 1998: Effects of lithium heparin and thripotassium EDTA on hematologic values of Hermann's tortoises (Testudo hermanni). J Zoo Wildl Med 29: 40-44

PAGÉS T, PEINADO VI, VISCOR G 1992: Seasonal changes in hematology and blood chemistry of the freshwater turtle Mauremys caspica leprosa. Comp Biochem Physiol A 103: 275-278

SAINT GIRONS MC 1970: In: Gans C (Ed) Biology of Reptilia. Vol., 3Academic Press Inc, New York, pp 73-91

SAMOUR H, HOWLETT JC, SILVANOSE C, HASBUN CR, AL-GHAIS SM 1998: Normal haematology of free-living green sea turtles (Chelonia mydas) from the United Arab Emirates. Comp Haematol Int 8: 102-107

SNIESHKUS E 1995: Europe pond turtle's (Emys orbicularis) reintroductions protect in Lithuania, 222-223, International Congress of Chelonian Conservation, (Soptom, ed.), Gonfaron, France, 243p.

SYPEK J, BORYSENKO M 1988: In: ROWLEY AF, RATCLIFFE NA (Eds.) Vertebrate blood cells. Cambridge University Press, Cambridge, pp. 211-256

UGURTAS IH, SEVINÇ M, YILDIRIMHAN HS 2003: Erythrocyte size and morphology of some tortoises and turtles from Turkey. Zool Stud 42: 173-178

WORK TM, RASKIN RE, BALASZ GH, WHITTAKER SD 1998: Morphologic and cytochemical characteristics of blood cells from Hawaiian green turtles. Amer J Vet Res 59: 1252-1257

ZUNIGA-GONZALEZ G, TORRES-BUGARIN O, LUNA-AGUIRRE J, GONZALEZ-RODRIGUEZ A, ZAMORA-PEREZ A, GOMEZ-MEDA BC, VENTURA-AGUILAR AJ, RAMOS-IBARRA ML, RAMOSMORA A, ORTIZ GG, GALLEGOS-ARREOLA MP 2000: Spontaneous micronuclei in peripheral blood erythrocytes from 54 animal species (mammals, reptiles and bird): part two. Mutat Res 467: 99-103 
Plate II

Metin K. et al.: Blood Cell Morphology ... pp. 49-55

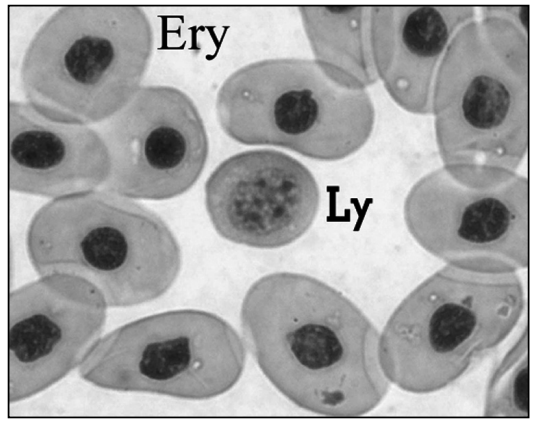

A

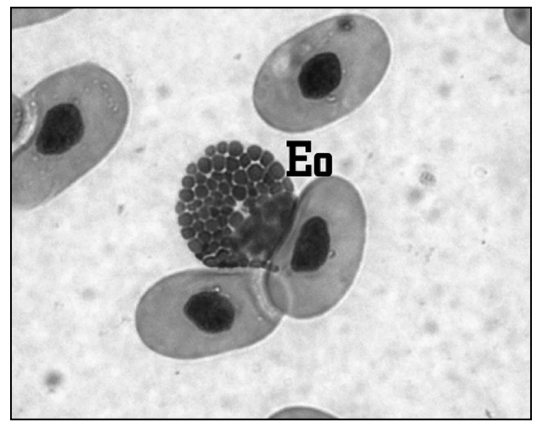

B

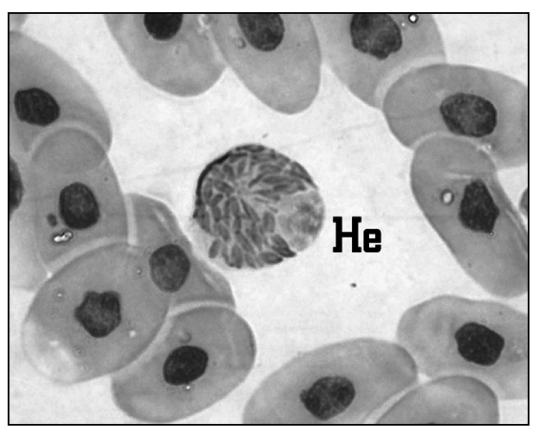

C

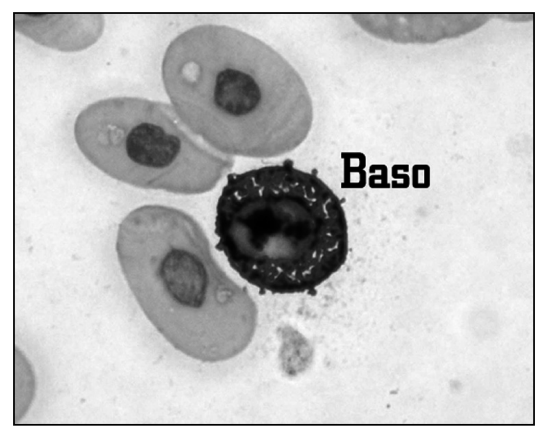

D

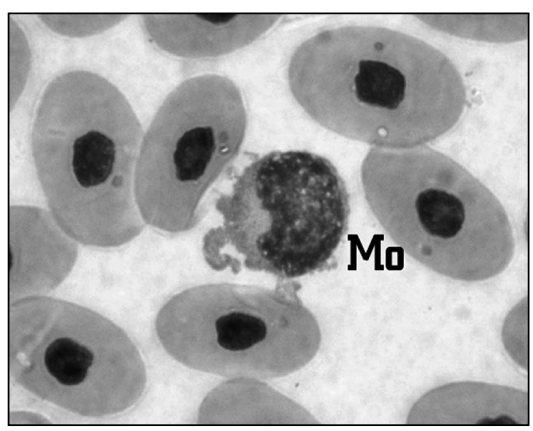

E

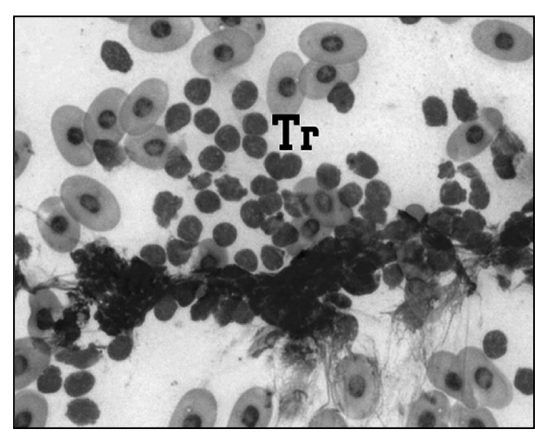

F

Fig. 1. Blood cells of the captive European pond turtle Emys orbicularis. A: Erythrocytes and Lymphocytes B: Eosinophils C: Heterophils D: Basophils E: Monocytes F: Thrombocytes 